$\xi=$

\title{
Assessing the creditworthiness of construction enterprises by different methods
}

\author{
Anna A. Shkileva * \\ Industrial University of Tyumen, Tyumen, Russia \\ *Corresponding author E-mail: shkileva.aa.tyuiu@gmail.com
}

\begin{abstract}
The article presents an assessment of the creditworthiness of a construction company with the help of three methods: the classical method of rating the enterprise, the methodology of R.S. Sayfullin and G.G. Kadykov, the methodology of the PJSC "Savings Bank of Russia". A comparison of these methods was carried out using the example of "Mostostroy-11".
\end{abstract}

Keywords: Creditworthiness; Assessment of the Borrower's Creditworthiness; Methods of Assessing the Creditworthiness of the Borrower.

\section{Introduction}

Many construction organizations cannot carry out their core business in full without additional funds. The procedure for assessing the creditworthiness of the borrower is to determine the ability to timely and fully repay debt obligations. Currently, there is no single standardized credit rating system in the world. Therefore, banks use different methods of analyzing the borrower's creditworthiness.

\section{Subjects and method}

The creditworthiness of "Mostostroy-11" was determined using three methods:

1) The classical method of rating the enterprise (as solved by Savitskaya [1]).

2) Methodology of R.S. Sayfullin and G.G. Kadykov (as solved Sheremet [2]).

3) Methodology of the PJSC "Savings Bank of Russia" (as solved PJSC "Savings bank of Russia" [3]).

In accordance with the classical methodology of the rating of the enterprise, first of all, it is necessary to group assets and liabilities (Table 1), analyze the liquidity of the balance sheet (Table 2 ).

Table 1: Grouping of Assets and Liabilities of "Mostostroy-11"

\begin{tabular}{|c|c|c|c|}
\hline Indicators & 2015 & 2016 & 2017 \\
\hline \multicolumn{4}{|l|}{ Assets } \\
\hline A1 - most liquid assets & 105946.00 & 66284.00 & 177472.00 \\
\hline A2 - quick assets & 2192002.00 & 2722723.00 & 3692953.00 \\
\hline A3 - slow-moving assets & 2825006.00 & 4058423.00 & 6168611.00 \\
\hline A4 - hard-to-sell assets & 2223460.00 & 2724675.00 & 4181615.00 \\
\hline BALANCE & 7346414.00 & 9572105.00 & 14220651.00 \\
\hline \multicolumn{4}{|l|}{ Liabilities } \\
\hline $\begin{array}{l}\text { P1 - most urgent } \\
\text { obligations }\end{array}$ & 2126576.00 & 3019954.00 & 4442109.00 \\
\hline P2 - short-term liabilities & 1289643.00 & 307910.00 & 407726.00 \\
\hline P3 - long-term liabilities & 184046.00 & 1831794.00 & 3892324.00 \\
\hline P4 - standing liabilities & 3746149.00 & 4412447.00 & 5478492.00 \\
\hline BALANCE & 7346414.00 & 9572105.00 & 14220651.00 \\
\hline
\end{tabular}

Table 2: Compliance with the Liquidity Conditions of the Balance Sheet

\begin{tabular}{llll}
\hline Assets & 2015 & 2016 & 2017 \\
\hline $\mathrm{A}_{1} \geq \mathrm{P}_{1}$ & - & - & - \\
$\mathrm{A}_{2} \geq \mathrm{P}_{2}$ & + & + & + \\
$\mathrm{A}_{3} \geq \mathrm{P}_{4}$ & + & + & + \\
$\mathrm{A}_{4} \leq \mathrm{P}_{4}$ & + & + & + \\
\hline
\end{tabular}

The received liquidity ratios of "Mostostroy-11" balance sheet indicate the insufficiency of the most liquid assets (A1) to cover its current liabilities. This is possible only by $73 \%$ in $2015,71 \%$ in 2016 and by $67 \%$ in 2017 . Although in the implementation of fasttrack assets (A2), funds to repay the most urgent obligations are sufficient.

The calculation of creditworthiness ratios is presented in Table 3, the borrower's classification by credit quality is shown in Table 4 .

Table 3: Calculation of Credit Ratios

\begin{tabular}{llll}
\hline Index & 2015 & 2016 & 2017 \\
\hline Balance sheet liquidity ratio & 0.73 & 0.71 & 0.67 \\
Absolute liquidity ratio & 1.50 & 2.06 & 2.07 \\
Coefficient of quick liquidity & 0.67 & 0.84 & 0.80 \\
Coefficient of current liquidity & 0.03 & 0.02 & 0.04 \\
Coefficient of autonomy & 0.51 & 0.46 & 0.39 \\
\hline
\end{tabular}

Table 4: Credit Rating by Borrower

\begin{tabular}{|c|c|c|c|c|}
\hline Index & First class & $\begin{array}{l}\text { Second } \\
\text { class }\end{array}$ & Third class & $\begin{array}{l}\text { Share } \\
\%\end{array}$ \\
\hline $\begin{array}{l}\text { Coefficient of cur- } \\
\text { rent liquidity (Coef- } \\
\text { ficient of coverage) }\end{array}$ & $\begin{array}{l}2 \text { and } \\
\text { higher }\end{array}$ & $1.0-2.0$ & $\begin{array}{l}\text { Less than } \\
1.0\end{array}$ & 30 \\
\hline $\begin{array}{l}\text { Coefficient of quick } \\
\text { liquidity }\end{array}$ & $\begin{array}{l}1.0 \text { and } \\
\text { higher }\end{array}$ & $0.5-1.0$ & $\begin{array}{l}\text { Less than } \\
0.5\end{array}$ & 20 \\
\hline $\begin{array}{l}\text { Absolute liquidity } \\
\text { ratio }\end{array}$ & $\begin{array}{l}0.2 \text { and } \\
\text { higher }\end{array}$ & $0.15-0.2$ & $\begin{array}{l}\text { Less than } \\
0.15\end{array}$ & 30 \\
\hline $\begin{array}{l}\text { Coefficient of } \\
\text { autonomy }\end{array}$ & $\begin{array}{l}0.7 \text { and } \\
\text { higher }\end{array}$ & $0.5-0.7$ & $\begin{array}{l}\text { Less than } \\
0.5\end{array}$ & 20 \\
\hline
\end{tabular}

Based on the calculated coefficients, taking into account the borrower's classification by the level of creditworthiness, the rating of "Mostostroy-11" was carried out (table 5).

Table 5: Calculation of the Rating of "Mostostoroy-11" 


\begin{tabular}{|c|c|c|c|c|c|c|c|}
\hline \multirow[b]{2}{*}{ Index } & \multirow[b]{2}{*}{$\begin{array}{l}\text { Indicator } \\
\text { weight }\end{array}$} & \multicolumn{2}{|l|}{2015} & \multicolumn{2}{|l|}{2016} & \multicolumn{2}{|c|}{2017} \\
\hline & & $\begin{array}{l}\text { Val } \\
\text { ue }\end{array}$ & $\begin{array}{l}\mathrm{Cl} \\
\text { ass }\end{array}$ & $\begin{array}{l}\text { Val } \\
\text { ue }\end{array}$ & $\begin{array}{l}\mathrm{Cl} \\
\text { ass }\end{array}$ & $\begin{array}{l}\text { Val } \\
\text { ue }\end{array}$ & $\begin{array}{l}\mathrm{Cl} \\
\text { ass }\end{array}$ \\
\hline $\begin{array}{l}\text { Coefficient of } \\
\text { current liquidity }\end{array}$ & $30 \%$ & 1.5 & 2 & $\begin{array}{l}2.0 \\
6\end{array}$ & 1 & $\begin{array}{l}2.0 \\
7\end{array}$ & 1 \\
\hline $\begin{array}{l}\text { Coefficient of } \\
\text { quick liquidity }\end{array}$ & $20 \%$ & 0.7 & 2 & $\begin{array}{l}0.8 \\
7\end{array}$ & 2 & $\begin{array}{l}0.8 \\
2\end{array}$ & 2 \\
\hline $\begin{array}{l}\text { Absolute liquidity } \\
\text { ratio }\end{array}$ & $30 \%$ & $\begin{array}{l}0.0 \\
3\end{array}$ & 3 & $\begin{array}{l}0.0 \\
2\end{array}$ & 3 & $\begin{array}{l}0.0 \\
4\end{array}$ & 3 \\
\hline $\begin{array}{l}\text { Coefficient of } \\
\text { autonomy }\end{array}$ & $20 \%$ & $\begin{array}{l}0.5 \\
1\end{array}$ & 2 & $\begin{array}{l}0.4 \\
6\end{array}$ & 3 & $\begin{array}{l}0.3 \\
9\end{array}$ & 3 \\
\hline Sum of points: & $100 \%$ & & $\begin{array}{l}23 \\
0 \\
\end{array}$ & & $\begin{array}{l}22 \\
0 \\
\end{array}$ & & $\begin{array}{l}22 \\
0 \\
\end{array}$ \\
\hline
\end{tabular}

The results of the calculations showed that throughout the whole period of the study the enterprise can be attributed to the second class of borrowers, therefore, the bank can issue a loan to it in the usual way, provided that there are corresponding obligations (guarantees, pledge, etc.).

Methodology R.S. Sayfullin and G.G. Kadykov is an attempt to adapt the "Z-score" model of E. Altman to Russian conditions. The normative values of the coefficients used do not take into account the sectoral features of the organization, the model can be applied to enterprises of various scales. This method of diagnosis was built taking into account the specifics of Russian business, so it seems most optimal for use. In this methodology, 5 indicators are used, most often used and fully characterize the financial condition of the enterprise.

This method consists in calculating the rating number "R":

$\mathrm{R}=2 \mathrm{~K}_{\mathrm{se}}+0.1 \mathrm{~K}_{\mathrm{liq}}+0.08 \mathrm{~K}_{\mathrm{int}}+0.45 \mathrm{~K}_{\mathrm{man}}+\mathrm{K}_{\mathrm{ret}}$

Where $\mathrm{K}_{\mathrm{se}}$ - equity ratio;

$\mathrm{K}_{\text {liq }}$ - current ratio;

$\mathrm{K}_{\text {int }}$ - turnover rate of advanced capital;

$K_{\text {man }}$ - the management coefficient, is characterized by the ratio of the profit from sales to the amount of revenue from sales;

$\mathrm{K}_{\text {ret }}$ - return on equity.

Table 6 presents the results of calculation of the rating number for "Mostostroy-11":

Table 6: Results of Calculation of the Rating Number for "Mostostroy-11"

\begin{tabular}{llll} 
Table 6: Results of Calculation of the Rating Number for & \multicolumn{3}{l}{ Mostroy-11" } \\
\hline \multirow{2}{*}{ Index } & 201 & 201 & 201 \\
& 5 & 6 & 7 \\
\hline 1. Coefficient of supply with own reserves $\mathrm{K}_{\mathrm{se}}$ & 0.3 & 0.2 & 0.1 \\
& 0 & 5 & 2 \\
2. Coefficient of current liquidity $\mathrm{K}_{\text {liq }}$ & 1.5 & 2.0 & 2.0 \\
& 0 & 6 & 5 \\
3. Intensity of turnover of the advancing capital $\mathrm{K}_{\text {int }}$ & 1.0 & 7.1 & 1.1 \\
& 0.0 & 2 & 7 \\
4. Coefficient of management $\mathrm{K}_{\text {man }}$ & 8 & 3 & 6 \\
& 0.3 & 0.5 & 0.6 \\
5. Profitability of own capital $\mathrm{K}_{\text {ret }}$ & 2 & 2 & 6 \\
6. Rating rating $\mathrm{R}=2 \mathrm{~K}_{\mathrm{se}}+0.1 \mathrm{~K}_{\text {liq }}+0.08 \mathrm{~K}_{\text {int }}+0.45$ & 1.1 & 1.3 & 1.2 \\
$\mathrm{~K}_{\mathrm{man}}+\mathrm{K}_{\mathrm{re}}$ & 8 & 6 & 8 \\
\hline
\end{tabular}

Substituting the values of the calculated coefficients in the general form of the model, we obtained the rating numbers equal to 1.18 ; 1.36 and 1.28 respectively for 2015,2016 and 2017. The financial condition of an enterprise with a rating of 1 or more is characterized as satisfactory, therefore, for "Mostostroy-11", this condition is met.

According to the methodology of the PJSC "Savings Bank of Russia", in order to determine the creditworthiness of the borrower, a quantitative risk analysis was carried out using three groups of estimated indicators (Table 7, 8):

- liquidity ratios;

- ratio of equity to borrowed funds;

- indicators of turnover and profitability.
Table 7: The Main Evaluation Indicators of the Methodology of the PJSC "Savings Bank of Russia"

\begin{tabular}{|c|c|c|}
\hline$\#$ & Indicator name & Explanation \\
\hline 1. & $\begin{array}{l}\text { K } 1 \text { - Absolute } \\
\text { liquidity ratio }\end{array}$ & $\begin{array}{l}\text { Shows how much of the short-term debt } \\
\text { can be repaid, if necessary, from available } \\
\text { funds, funds on deposit accounts and high- } \\
\text { ly liquid short-term securities. }\end{array}$ \\
\hline 2. & $\begin{array}{l}\text { K } 2 \text { - Intermediate } \\
\text { coverage ratio (quick } \\
\text { liquidity ratio) }\end{array}$ & $\begin{array}{l}\text { It characterizes the enterprise's ability to } \\
\text { promptly release money from the econom- } \\
\text { ic circulation and pay off debt obligations. }\end{array}$ \\
\hline 3. & $\begin{array}{l}\text { K } 3 \text { - Coefficient of } \\
\text { current liquidity (total } \\
\text { coverage ratio) }\end{array}$ & $\begin{array}{l}\text { Gives an overall assessment of the liquidi- } \\
\text { ty of the enterprise, in the calculation of } \\
\text { which the numerator includes all current } \\
\text { assets }\end{array}$ \\
\hline 4. & K 4 - Equity ratio & $\begin{array}{l}\text { Shows the share of the enterprise's own } \\
\text { funds in the total amount of the enterprise's } \\
\text { funds. }\end{array}$ \\
\hline 5. & $\begin{array}{l}\text { K } 5 \text { - Profitability of } \\
\text { sales }\end{array}$ & $\begin{array}{l}\text { Shows the share of sales profit from sales } \\
\text { revenue }\end{array}$ \\
\hline
\end{tabular}

Table 8: The Differentiation of Indicators by Category

\begin{tabular}{llll}
\hline Coefficients & First class & Second class & Third class \\
\hline K 1 & 0.2 and higher & $0.1-0.2$ & Less than 0.15 \\
K 2 & 0.8 and higher & $0.5-0.8$ & Less than 0.5 \\
K 3 & 2.0 and higher & $1.0-2.0$ & Less than 1.0 \\
K 4 & 1.0 and higher & $0.7-1.0$ & Less than 0.7 \\
K 5 & 0.15 and higher & Less than 0.15 & Unprofitable \\
\hline
\end{tabular}

\section{Results}

Evaluation of the calculation results of the five main assessment coefficients (the first and second groups) consisted in assigning to the Borrower a category for each of these indicators, based on a comparison of the values obtained with the established ones. Next, the sum of scores for these indicators was determined in accordance with their scales. The results of the calculations are presented in Tables 9-11.

Table 9: Calculation of Scores (2015)

\begin{tabular}{lllll} 
& \multicolumn{3}{c}{ Table 9: Calculation of Scores (2015) } \\
\hline Index & $\begin{array}{l}\text { Actual } \\
\text { value }\end{array}$ & Category & $\begin{array}{l}\text { Indicator } \\
\text { weight }\end{array}$ & $\begin{array}{l}\text { Calculation of the } \\
\text { score }\end{array}$ \\
\hline K 1 & 0.02 & 3 & 0.11 & 0.33 \\
K 2 & 0.69 & 2 & 0.05 & 0.1 \\
K 3 & 1.36 & 2 & 0.42 & 0.84 \\
K 4 & 0.23 & 3 & 0.21 & 0.63 \\
K 5 & 0.07 & 2 & 0.21 & 0.42 \\
S & x & x & 1 & 2.32 \\
\hline
\end{tabular}

Table 10: Calculation of Scores (2016)

\begin{tabular}{lllll}
\hline Index & $\begin{array}{l}\text { Actual } \\
\text { value }\end{array}$ & Category & $\begin{array}{l}\text { Indicator } \\
\text { weight }\end{array}$ & $\begin{array}{l}\text { Calculation of the } \\
\text { score }\end{array}$ \\
\hline K 1 & 0.03 & 3 & 0.11 & 0.33 \\
K 2 & 0.7 & 2 & 0.05 & 0.1 \\
K 3 & 1.5 & 2 & 0.42 & 0.84 \\
K 4 & 0.3 & 3 & 0.21 & 0.63 \\
K 5 & 0.12 & 2 & 0.21 & 0.42 \\
S & x & x & 1 & 2.32 \\
\hline
\end{tabular}

\begin{tabular}{lllll} 
& \multicolumn{3}{c}{ Table 11: Calculation Of Scores (2017) } \\
\hline Index & $\begin{array}{l}\text { Actual } \\
\text { value }\end{array}$ & Category & $\begin{array}{l}\text { Indicator } \\
\text { weight }\end{array}$ & $\begin{array}{l}\text { Calculation of the } \\
\text { score }\end{array}$ \\
\hline K 1 & 0.02 & 3 & 0.11 & 0.33 \\
K 2 & 0.87 & 1 & 0.05 & 0.05 \\
K 3 & 2.06 & 1 & 0.42 & 0.42 \\
K 4 & 0.25 & 3 & 0.21 & 0.63 \\
K 5 & 0.16 & 1 & 0.21 & 0.21 \\
S & x & x & 1 & 1.64 \\
\hline
\end{tabular}

Other indicators of turnover and profitability (Table 12,13) (the third group) were used for general characteristics and considered as additional to the first five indicators. 


\begin{tabular}{llll}
\hline Index & 2015 & 2016 & 2017 \\
\hline $\begin{array}{l}\text { Coefficient of turnover of liquid assets, in turn- } \\
\text { over }\end{array}$ & 74.43 & 161.0 & 9 \\
Duration of turnover of liquid assets, in days & 4.84 & 2.24 & 3.84 \\
$\begin{array}{l}\text { Coefficient of turnover of inventory, in revolu- } \\
\text { tions }\end{array}$ & 2.66 & 2.34 & 2.34 \\
Duration of turnover of inventory in days & 135.4 & 153.5 & 153.8 \\
Coefficient of turnover of circulating assets, in & 8 & 3 & 2 \\
revolutions & 1.54 & 1.56 & 1.67 \\
Duration of turnover of working capital, in days & 233.8 & 230.9 & 215.3 \\
Asset turnover ratio, in turnover & 1.07 & 2 & 0 \\
Duration of assets turnover, in days & 335.3 & 322.8 & 307.3 \\
Factor of turnover of own capital, in revolutions & 2.11 & 2.42 & 0 \\
Duration of turnover of own capital, in days & 171.0 & 148.8 & 118.3 \\
Coefficient of turnover of accounts receivable, & 2 & 0 & 9 \\
in revolutions & 3.65 & 3.98 & 4.77 \\
Repayment period of receivables, in days & 98.75 & 90.53 & 75.51 \\
\hline
\end{tabular}

Table 13: Dynamics of Profitability Indicators of "Mostostroy-11"

\begin{tabular}{llll}
\hline Index & 2015 & 2016 & 2017 \\
\hline Profitability of ROS operations, \% & 7.5 & 12.8 & 16.2 \\
Net profit margin, \% & 4 & 6 & 7 \\
Profitability of ROM products, $\%$ & 4.2 & 7.3 & 8.5 \\
Return on assets ROA & 0.04 & 0.07 & 0.08 \\
Return on equity ratio ROE & 0.08 & 0.15 & 0.22 \\
\hline
\end{tabular}

\section{Conclusion}

Based on the results of the assessment of the creditworthiness of "Mostostroy-11" with the help of PJSC "Savings Bank of Russia" methodology, it can be concluded that this enterprise belongs to the second class of creditworthiness, the lending of which requires a balanced approach. Improvement of profitability indicators, as well as indicators of turnover over the period under review, can only positively influence the determination of the rating of "Mostostroy-11" when assessing its creditworthiness.

Thus, by analyzing the creditworthiness of "Mostostroy-11" with the help of three methods (as solved Shkileva [4]), it can be said that this organization retains the ability to repay its liabilities at the expense of production stocks, finished goods, receivables and other current assets. There are also opportunities to raise additional borrowed funds without the risk of losing financial stability.

\section{References}

[1] Savitskaya GV, Analysis of the economic activity of the enterprise, Infra-M, Moscow, (2009), pp: 1-536.

[2] Sheremet AD \& Sayfulin RS, Methods of financial analysis, InfraM, Moscow, (2004), pp: 1-176.

[3] PJSC "Savings bank of Russia", the credit rating of the borrower by the method of Sberbank, Retrieved from http://afdanalyse.ru/publ/finansovyj_analiz/ocenka_kreditosposobn osti/metodika_sb/29-1-0-43.

[4] Shkileva AA \& Sidorenko OV, Estimation of the economic effect of the use of adjustable ac electric drive at pumping stations. International Journal of Civil Engineering and Technology, 9(5), (2018), pp. 589-593. 